\title{
Perbandingan Karakteristik Kimiawi Ekstrak Brokoli Terfermentasi dengan Variasi Konsentrasi Kultur Kambucha Sebagai Minuman Fungsional
}

\author{
Yati Maryati, Agustine Susilowati, Puspa D. Lotulung \\ Pusat Penelitian Kimia LIPI, Kawasan Puspiptek Serpong, Tangerang 15310 \\ Indonesia \\ *Corresponding author: maryati97@yahoo.com
}

\begin{abstract}
ABSTRAK
Minuman fungsional berbasis sayuran terfermentasi terus dikembangkan. Ekstrak brokoli yang difermentasi oleh starter kultur kombucha atau SCOBY (a symbiotic colony of yeast) dapat berkhasiat sebagai minuman probiotik yang ditujukan untuk meningkatkan kesehatan, mengeluarkan racun dalam tubuh, meningkatkan antibodi, memperbaiki dan memaksimalkan fungsi organ tubuh. Tujuan penelitian ini dilakukan untuk mengetahui perbandingan karakteristik kimiawi hasil fermentasi ekstrak brokoli dengan konsentrasi kultur yang berbeda sebagai minuman fungsional yang dilakukan terhadap perubahan kadar total asam, total polifenol, gula reduksi, dan identifikasi antioksidan dari kondisi optimum. Formulasi ekstrak brokoli difermentasi dengan variasi kultur starter kambucha sebesar 15\%, 25\% dan 35\%v/v, dievaluasi terhadap perubahan karakteristik selama waktu fermentasi (0, 6, dan 12 hari). Hasil penelitian memperlihatkan bahwa fermentasi minuman fungsional brokoli dengan konsentrasi kultur starter yang berbeda berpengaruh terhadap total polifenol, total asam dan total sel bakteri, dan identifikasi antioksidan yang dihasilkan. Kondisi optimum diperoleh pada konsentrasi kultur starter kambucha $15 \%$ selama fermentasi 6 hari berdasarkan total asam 3,63\%, protein terlarut 0,29mg/mL, gula reduksi $272.81 \mathrm{mg} / \mathrm{mL}$, total polifenol 0,58\%. Identifikasi antioksidan pada ektrak sayuran brokoli pada kondisi optimum juga dilakukan analisa melalui LC-MS.
\end{abstract}

DOI: https://doi.org/10.25026/jsk.v1i10.92

\section{PENDAHULUAN}

Penggalian potensi senyawa bioaktif dari alam untuk produk pangan menjadi perhatian yang tidak mengenal batas waktu. Produk pangan fungsional merupakan pangan yang karena kandungan komponen aktifnya dapat memberikan manfaat bagi kesehatan. Broccoli (Brassica oleracea L.) yang difermentasi oleh kultur kombucha merupakan pengembangan proses fermentasi sebagai upaya penting dalam memproduksi senyawa bioaktif, terutama asam organik dan polifenol untuk antioksidan. Baru-baru ini, potensi penggunaan brokoli sebagai antioksidan alami belum pernah dieksplorasi dan masih terbatas untuk kebutuhan gizi manusia.

Kombucha merupakan kumpulan dari bakteri (yang menguntungkan tubuh) dan ragi yang hidup berkoloni membentuk kultur struktur selulosa seperti gelatin; lapisan ini disebut juga sebagai Zooglea (lapisan yang hidup) disingkat dengan nama SCOBY (Symbiotic Culture of Bacteria and Yeast), dimana ragi akan memfermentasi nutrisi dari cairan dan akan terbentuk alkohol, selanjutnya bakteri akan mengubahnya menjadi asam yang menyehatkan bagi tubuh [1]. Oleh karenanya pengembangan pangan fungsional berbasis fermentasi sayuran akan terus dikembangkan. 
Dalam penelitian ini akan dikaji perubahan karakteristik kimiawi ekstrak brokoli terfermentasi dengan variasi konsentrasi kultur kambucha sebagai minuman fungsional yang bermanfaat bagi kesehatan tubuh.

\section{METODOLOGI}

\section{Bahan dan Peralatan}

Bahan bahan yang digunakan dalam penelitian ini adalah sayuran brokoli, sukrosa, SCOBY( a symbiotic colony of yeast ) kultur kombucha, sedangkan bahan kimia yang digunakan terdiri dari : PDA, natrium karbonat (Na2CO3), ethanol, Folin-Ciocalteau reagent, $\mathrm{HCl}, \mathrm{KH}_{2} \mathrm{PO}_{4}$, potassium ferric cyanide, trichloroacetic acid (TCA) (EMerck), NaOH, Buffer Fosfat. Sedangkan peralatan yang digunakan terdiri dari laminar flow system, water bath (Memmert, Germany), incubator, UV-Vis Spectrophotometer (Model RF-550, Shimadzu, Japan) and LC-MS (Mariner Biospectrometry) with LC (Hitachi L 6200).

\section{Tahapan Proses}

\section{Ekstraksi sayuran dan persiapan- inokulum kombucha sayuran brokoli} Sejumlah sayuran brokoli diblansing selama 5 menit pada suhu $80^{\circ} \mathrm{C}$. Sayuran brokoli dari proses blanshing tersebut dilumatkan dengan perbandingan 1 bagian sayuran dan 4 bagian air steril dan suspensi sayuran kemudian diperoleh. Suspensi sayuran hijau brokoli ini kemudian dilakukan penyaringan melalui saringan mesh 80 . Filtrat sayuran brokoli diperoleh, kemudian ditambahkan dengan sukrosa (10\%b/v filtrat sayuran), kultur kombucha $15 \%$ dan difermentasi selama 7 hari dalam wadah tertutup di ruangan gelap maka akan diperoleh inokulum kombucha sayuran brokoli yang digunakan untuk fermentasi selanjutnya.

\section{Proses fermentasi sayuran hijau brokoli dengan inokulum kombucha sayuran}

Filtrat sayuran hijau melalui proses yang sama dengan proses pembuatan inoculum kombucha sayuran brokoli digunakan pula sebagai substrat dalam proses fermentasi. Filtrat ditambahkan dengan inokulum masingmasing sebesar $15 \%, 25 \%$ dan $35 \%$ (v/v filtrat sayuran brokoli), selanjutnya ditambahkan sukrosa $(10 \% \mathrm{~b} / \mathrm{v}$ filtrat sayuran brokoli) dan disimpan dalam wadah dengan aerasi (ditutupi dengan kain kassa) dalam ruang gelap pada suhu kamar dan difermentasi selama 0, 6, dan 12 hari. Seluruh perlakuan dilakukan secara aseptik. Akumulasi biomassa setelah fermentasi diperoleh sebagai suspensi sayuran yang difermentasi sebagai minuman fungsional.

\section{Tahapan Analisis}

\section{Penentuan Total Polifenol}

Sumlah total fenolat sampel brokoli diuji dengan menggunakan spektrofotometer dengan cara metode Folin-Ciocalteu [2] 0,1 mL larutan sampel kedalam tabung reaksi, kemudian ditambahkan $0.7 \mathrm{~mL}$ aquadest, $0.5 \mathrm{~mL}$ reagen Folin-Dennis, $1 \mathrm{~mL}$ larutan natrium karbonat $\left(\mathrm{Na}_{2} \mathrm{CO}_{3}\right)$ dan ditambahkan $1.4 \mathrm{~mL}$ aquadest kemudian divortex. Selanjutnya diinkubasi selama 1 jam pada suhu $30^{\circ} \mathrm{C}$. Absorbansi diukur pada panjang gelombang $760 \mathrm{~nm}$ menggunakan spektrofotometer UV-Vis.

\section{Polifenol $(\%)=[\mathrm{C} / \mathrm{M} \times \mathrm{m} \times \mathrm{L} 2 / \mathrm{L} 1 \times$ 1000) $\times 100$}

$\mathrm{C}=$ Konsentrasi yang diperoleh dari kurva standar (mg GAE/mL)

L1 = Total volume pada preparasi sampel $(\mathrm{mL})$

L2 = Volume sampel

$\mathrm{m}=$ kadar padatan kering $(\%)$

$\mathrm{M}=$ berat sampel $(\mathrm{g})$ 


\section{Identifikasi antioksidan melalui LC- MS}

Setelah proses fermentasi, sayuran difermentasi kemudian disaring dengan membrane 0.45 mikrofiltrasi. Hasil saringan yang diperoleh atau filtrat dari sayuran yang difermentasi dan standar asam galat kemudian dianalisis dengan LC-MS. Analisis oligomer asam folat dilakukan oleh LC-MS menggunakan Mariner Biospectrometry. spektrometer dioperasikan dalam mode scan (100$1200 \mathrm{~m} / \mathrm{z}$ ) menggunakan Electro Spray Ionization system (ESI). Pemisahan kromatografi dilakukan pada kolom analitis Supelco C18 $(250 \mathrm{~mm} \times 2 \mathrm{~mm}$, ukuran partikel $5 \mu \mathrm{m}$ ). fase gerak terdiri dari larutan asam asetat $(0,3 \%)$ dan metanol yang mengandung $0,3 \%$ asam asetat pada laju alir $1,0 \mathrm{~mL} / \mathrm{menit}$. Volume injeksi $20 \mathrm{~mL}$ yang digunakan dalam analisis ini [3].

\section{HASIL DAN PEMBAHASAN}

\section{Karakteristik Kimia Sayuran Brokoli}

Perbedaan karakteristk kimia pada sayuran brokoli segar (Brassica oleracea
L.) (Fresh broccoli), brokoli yang telah melalui proses blansing pada $80^{\circ} \mathrm{C}$ selama 5 menit, serta pada brokoli yang dilumatkan pada rasio 1: 4 bagian brokoli dengan air menghasilkan bubur brokoli, selanjutnya ekstrak brokoli dilakukan penyaringan melalui saringan 80 mesh dihasilkan filtrat brokoli menunjukkan perbedaan dalam komposisi kimia, seperti pada Tabel 1. Perbedaan ini menunjukkan filtrat pada 80 mesh (brokoli ekstrak) mengandung $1,54 \%$ total padatan, lebih tinggi dibandingkan dengan $0,79 \%$ total padatan dalam bubur brokoli. Perbedaan ini tampak pada keseluruhan polifenol dalam bubur brokoli $(0,4740 \%)$ dan filtrat 80 mesh (brokoli ekstrak) $(0,1836 \%)$, lebih rendah dibandingkan dengan brokoli segar $(0,0179 \%)$.

Fermentasi sayuran brokoli pada kondisi proses fermentasi $0-12$ hari menggunakan inokulum sayuran dengan kultur kombucha pada suhu ruang. Hasil fermentasi ekstrak brokoli yang telah mengalami fermentasi masing-masing diperlihatkan pada Gambar 1.

Tabel 1. Komposisi brokoli sebagai substrat dalam fermentasi kultur kombucha.

\begin{tabular}{lcc}
\hline \multirow{2}{*}{\multicolumn{1}{c}{ Type }} & \multicolumn{2}{c}{ Composition } \\
\cline { 2 - 3 } & Total Padatan (\%) & Total polifenol (\%) \\
\hline Fresh brokoli & 25.51 & 0.0179 \\
Blanching brokolii* & 0.5129 & 0.2704 \\
Bubur Brokoli** & 0.79 & 0.4740 \\
Ekstrak Broccoli $* * *$ & 1.54 & 0.1836
\end{tabular}

Ket : *hasil blansing $80^{\circ} \mathrm{C}$ selama 5 minutes, **Pelumatan dengan campuran 1 bagian broccoli and 4 bagian air, ***filtered/penyaringan melalui 80 mesh.
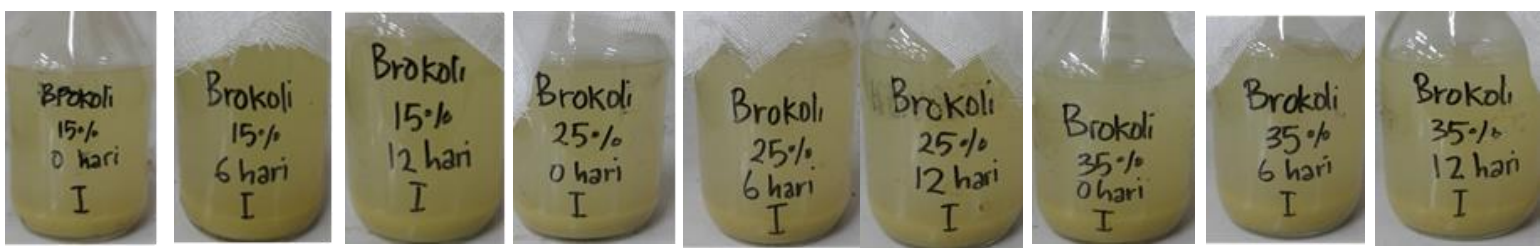

Gambar 1. Fermentasi ekstrak brokoli dengan inokulum kultur kombucha brokoli konsentrasi 15\%,25\%,dan 35\% dengan waktu fermentasi 0, 6 dan 12 hari pada suhu ruang 


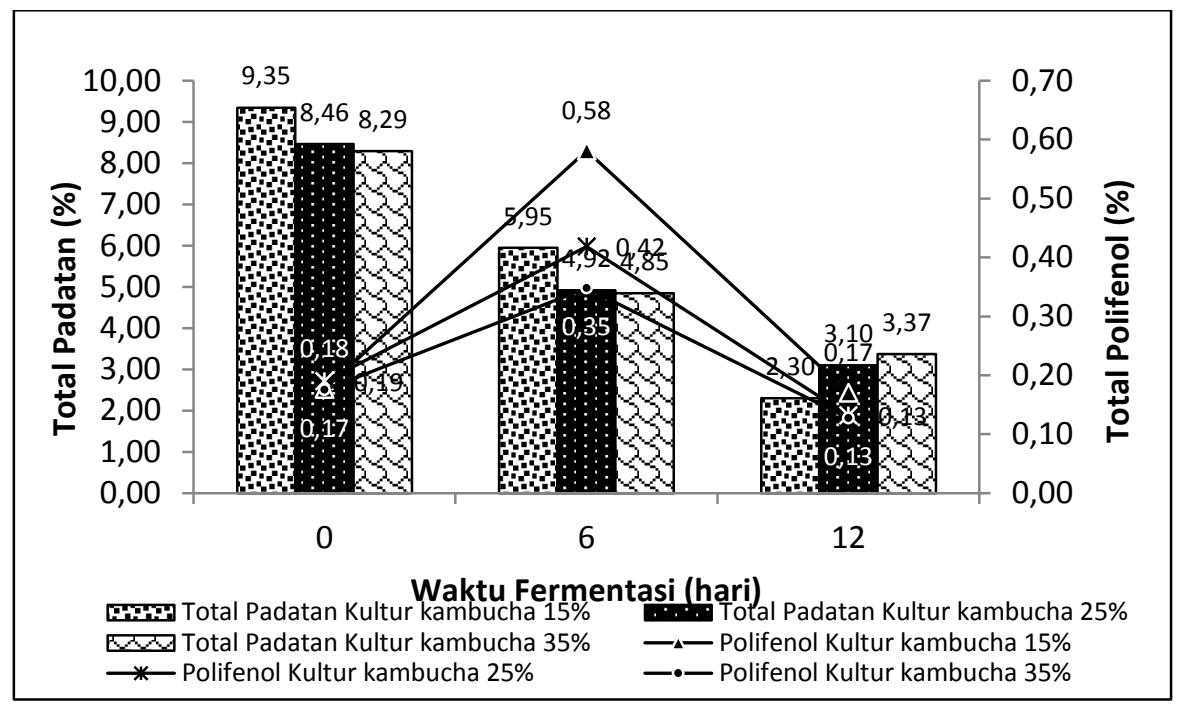

Gambar 2. Pengaruh waktu fermentasi dan konsentrasi inokulum terhadap kandungan total padatan dan polifenol hasil fermentasi ekstrak brokoli menggunakan kultur kombucha.

\section{Total Padatan dan Total Polifenol}

Waktu fermentasi ekstrak brokoli menggunakan inokulum kombucha pada suhu kamar memberikan perubahan terhadap total padatan. Semakin lama waktu fermentasi menghasilkan penurunan total padatan. Kandungan total padatan dari fermentasi ekstrak brokoli turun dari $9,35 \%$ menjadi $2,30 \%$ pada kultur kombucha $15 \%$, pada konsentrasi kultur kombucha $25 \%$ terjadi penurunan total padatan dari 8,46\% menjadi 3,10\% begitupula pada konsentrasi kultur 35\% terjadi penurunan total padatan dari $8,29 \%$ menjadi 3,37\% setelah 12 hari fermentasi. Penurunan kandungan padatan total selama fermentasi ini disebabkan oleh meningkatnya aktivitas mikroba selama proses fermentasi karena mikroorganisme membutuhkan lebih banyak air dan nutrisi dari senyawa bioaktif untuk metabolisme mereka. Perubahan total polifenol yang diperoleh selama fermentasi ditunjukkan pada Gambar 2.

Kandungan total polifenol meningkat secara logaritmik selama waktu fermentasi pada setiap konsentrasi kultur yang berbeda, Terjadinya peningkatan kandungan polifenol dari 0 hari ke hari ke 6 dan mengalami penurunan setelah fermentasi dihari ke-
12. Polifenol tertinggi pada waktu hari ke 6 diperoleh masing-masing sebesar $0,35 \%, 0,42 \%$ dan $0,58 \%$ pada kultur kombucha $(15,25$ dan 35\%).

Senyawa polifenol disebut antioksidan tingkat tinggi karena senyawa aktif memiliki kemampuannya untuk menangkal radikal bebas. Senyawa polifenol kompleks pada sayuran yang difermentasi dapat mengalami degradasi pada lingkungan asam dari enzim yang dihasilkan oleh oleh bakteri dan ragi dalam kultur kombucha brokoli. Oleh karenanya ada banyak kemungkinan enzim yang dibebaskan oleh bakteri dan ragi selama fermentasi kombucha akan mendegradasi polifenol kompleks menjadi molekul kecil yang pada gilirannya menghasilkan peningkatan senyawa total fenolik [4]. Selain itu, perubahan warna klorofil sayuran terfermentasi dengan kombucha menjadi lebih pudar ini menunjukkan bahwa polifenol memang mengalami transformasi mikroba karena penekanan ionisasi atau penghancuran struktur [5]. Oleh karenanya dimungkinkan starter kultur kombucha mengeluarkan beberapa enzim lainnya yang mampu mengkatalisis biodegradasi polifenol. Selain itu pendegradasian warna terjadi karena 
mikroba yang memanfaatkan Total Soluble Solid sebagai energi sehingga lama kelamaan pelarut dalam media akan habis dan cairan menjadi bening atau tidak berwarna [6].

Namun, kandungan total polifenol tidak selalu menentukan aktivitas antioksidan sedangkan jenis metabolit yang dihasilkan mungkin memiliki pengaruh yang besar [7].

\section{Protein Terlarut dan Aktivitas Proteolitik}

Protein terlarut yang dihasilkan pada inokulum fermentasi sayuran merupakan parameter pemecahan protein dengan berat molekul yang besar menjadi asam-asam amino dan peptida menjadi berat molekul yang lebih rendah oleh aktifitas proteolitik mikroba dalam kultur kombucha, sehingga menghasilkan kelarutan dalam air yang lebih tinggi sebagai protein terlarut. Kecenderungan kandungan protein terlarut dan aktivitas proteolitik menunjukkan pola yang sama dari masing-masing konsentrasi kultur kombucha selama proses fermentasi, terlihat dari pola perubahan kenaikan dan penurunan. Oleh karena besarnya protein terlarut turut dipengaruhi oleh enzim protease dari mikroba, maka dapat diasumsikan jika mikroba proteolitik tidak mendominasi kultur kombucha seperti terlihat pada Gambar 3.

Hal ini menunjukkan bahwa terjadinya perubahan protein terlarut secara logaritmik maka akan mempengaruhi nilai total polifenol dimana terjadi peningkatan pada hari ke 6 dan penurunan pada hari ke-12. Penurunan kandungan polifenol selama fermentasi kemungkinan disebabkan oleh degradasi polifenol untuk pembentukan asam organik, asetaldehid, alkohol dan karbondioksida yang berperan dalam pembentukan aroma spesifik kombucha.

Optimisasi proses fermentasi berdasarkan tingginya protein terlarut dan aktivitas proteolitik sebagai sumber enzim dicapai pada kombinasi perlakuan waktu fermentasi 6 hari dengan konsentrasi kultur $15 \%$ dan $35 \%$ dengan kandungan protein terlarut masing - masing sebesar $0,29 \mathrm{mg} / \mathrm{mL}$ dan aktivitas proteolitik sebesr $0,64 \mathrm{U} / \mathrm{mL}$ pada konsentrasi $15 \%$ dan kandungan protein terlarut masingmasing sebesar $0,29 \mathrm{mg} / \mathrm{mL}$ dan aktivitas proteolitik sebesr $0,73 \mathrm{U} / \mathrm{mL}$ pada konsentrasi $35 \%$.

\section{Total Asam (\%) dan Total Sel $(\log \mathbf{c f u} / \mathbf{m L})$}

Total asam merupakan parameter penting dalam fermentasi dengan menggunakan kultur kombucha sedangkan kultur kombucha akan menghasilkan beberapa senyawa asam seperti asam asetat, asam laktat, asam glukonat dan asam glukuronat. Peningkatan asam yang semakin tinggi diduga karena bakteri dalam kombucha telah mengalami fase pertumbuhan logaritmik, bersamaan dengan itu bakteri yang mensintesis alkohol menjadi asam semakin banyak sehingga total asam yang dihasilkan juga semakin tinggi. Berdasarkan penelitian [8] menyatakan bahwa selama proses fermentasi kombucha, khamir akan memecah gula (sukrosa) menjadi glukosa dan fruktosa, dan menggunakan glukosa untuk metabolisme sel sehingga akan menghasilkan etanol dan karbondioksida $\left(\mathrm{CO}_{2}\right)$, selanjutnya etanol akan dioksidasi oleh bakteri asam asetat menjadi asam asetat [9]. 


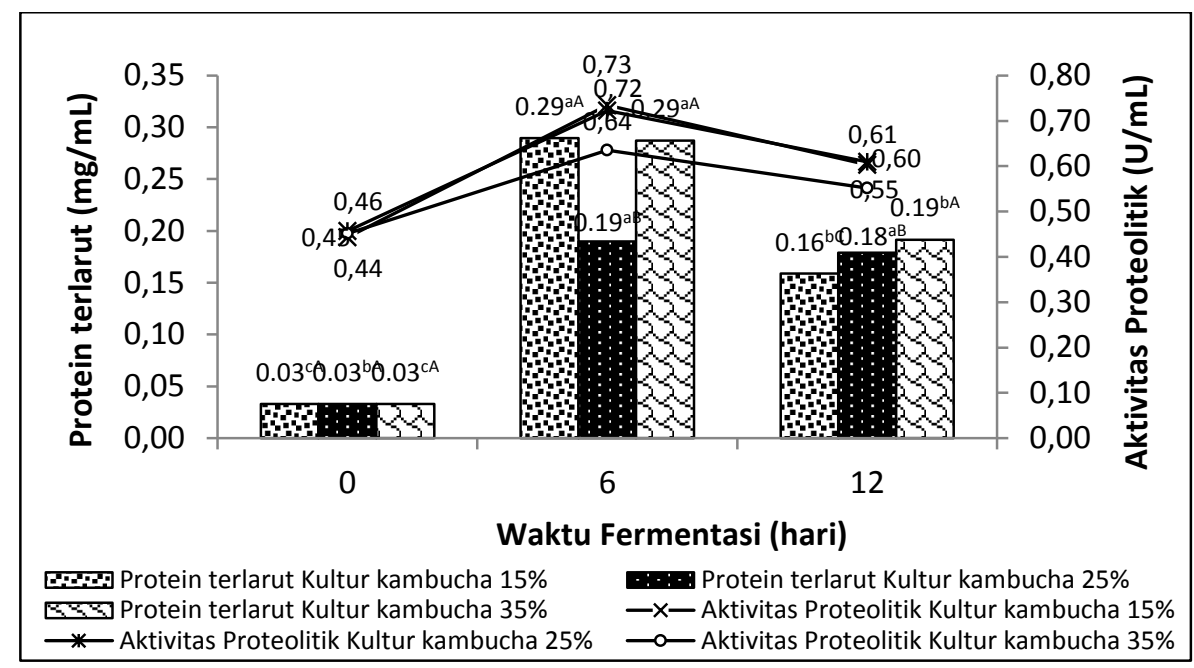

Gambar 3. Pengaruh waktu fermentasi dan konsentrasi inokulum terhadap kandungan protein terlarut dan aktivitas proteolitik hasil fermentasi ekstrak brokoli menggunakan kultur kombucha.

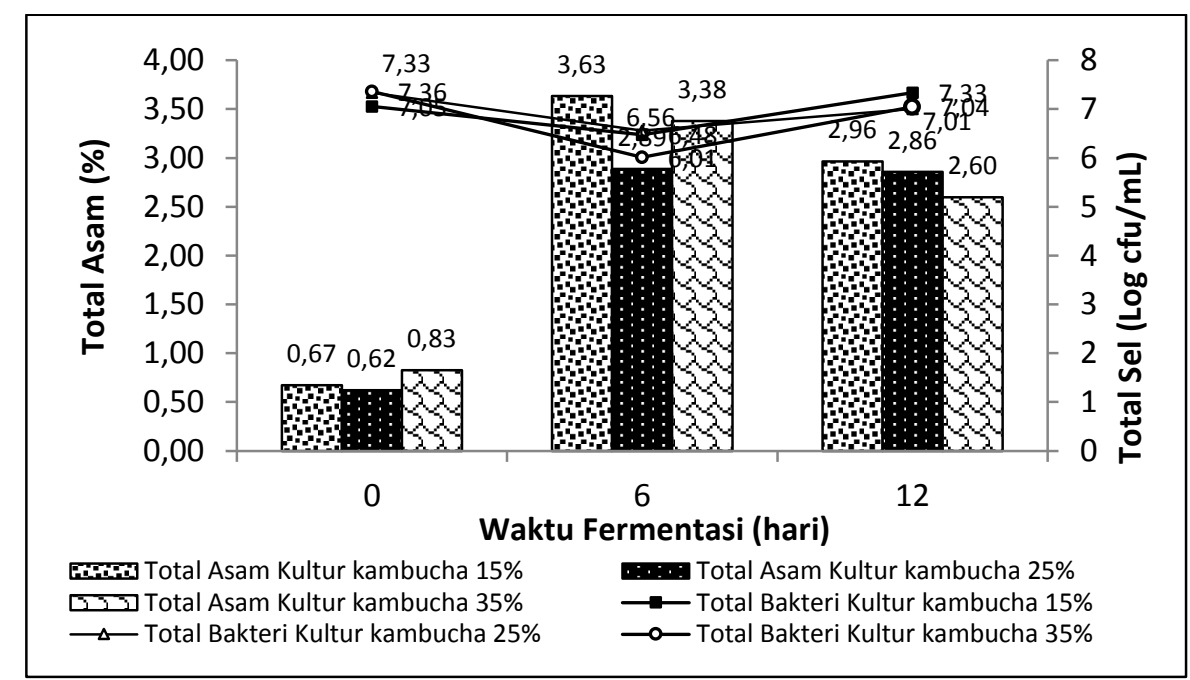

Gambar 4. Pengaruh waktu fermentasi dan konsentrasi inokulum terhadap kandungan Total Asam dan Total Sel hasil fermentasi ekstrak brokoli menggunakan kultur kombucha

Total asam dari fermentasi kombucha brokoli juga berkaitan dengan total sel yang diperoleh dimana mikroba akan menggunakan semua sukrosa dan komponen serat terlarut dari brokoli untuk membentuk asam organik seperti asam laktat, malat, asetat dan lainnya. Maka semakin tinggi total asam yang diperoleh akan meningkatkan pula total sel selama fermentasi berlangsung. Dengan bertambahnya waktu fermentasi, produksi asam akan meningkat hingga fase logaritmik namun akan mengalami fase statsioner akan mengalami penurunan karena laju kematian bakteri, seperti ditunjukkan pada Gambar 4. Total asam menghasilkan optimum pada waktu fermentasi 6 hari dan konsentrasi kultur $15 \%$ yaitu sebesar $3,63 \%$ dan total sel sebesar 7,33 log cfu/mL pada fermentasi brokoli. Berdasarkan Gambar 4, jumlah sel menurun secara bertahap pada periode fermentasi yang terakhir. Penurunan populasi mikroba pada akhir fermentasi disebabkan oleh penurunan senyawa karbon dan antimikroba yang ditemukan pada sayuran hijau brokoli termasuk senyawa asam organik yang dihasilkan. 
Gula Reduksi dan Aktivitas Amilolitik

Ragi dan bakteri yang terlibat dalam aktivitas metabolik fermentasi kultur kombucha brokoli yang memanfaatkan substrat dengan cara yang berbeda dan saling melengkapi. Sukrosa adalah sumber karbon yang paling umum dalam fermentasi kombucha. Ragi menghidrolisis sukrosa menjadi glukosa dan fruktosa oleh invertase dan menghasilkan etanol melalui glikolisis, dengan preferensi fruktosa sebagai substrat [10]. Aktivitas amilase pada sayuran hasil fermentasi menggunakan kombucha menunjukkan kemampuan mikroba untuk mengolah rantai karbohidrat menjadi unit disakarida yang lebih kecil. Gambar 5 menggambarkan aktivitas amilase dari sayuran yang difermentasi cukup berfluktuasi, namun kondisi optimum dari fermentasi brokoli mencapai pada hari keenam pada waktu fermentasi, dan dengan konsentrasi kultur kombucha $25 \%$ adalah sebesar 2472,22 $\mathrm{U} / \mathrm{mL}$. Laporan sebelumnya menunjukkan bahwa amilase dapat dihambat oleh monomer senyawa fenolik. Dengan demikian, penurunan aktivitas amilase bisa jadi karena fraksi fenolik yang dihasilkan pada sayuran fermentasi dengan menggunakan kombucha culture [11].

Aktivitas amilase mikroba terkait erat dengan gula reduksi yang dihasilkan selama proses fermentasi kombucha brokoli. Sukrosa dihidrolisis oleh invertase. Kombucha menjadi glukosa dan fruktosa, secara simbiosis digunakan sebagai sumber karbon. Gula reduksi merupakan parameter pembentukan monosakarida yang terhidrolisis oleh enzim amilase. Berdasarkan Gambar 5, gula reduksi selama proses fermentasi berfluktuasi. Namun, penurunan gula mencapai optimum pada hari keenam fermentasi dengan konsentrasi kultur 25\% kultur kombucha brokoli, yaitu sebesar $278,82 \mathrm{mg} / \mathrm{mL}$. Terlihat bahwa hasil yang diperoleh berbanding lurus dengan kondisi optimum aktivitas amilase yang diperoleh selama fermentasi sayuran hijau brokoli. Sukrosa memfasilitasi fermentasi Kombucha lebih baik daripada glukosa dan fruktosa [8]. Pemecahan sukrosa oleh Ragi Kombucha menjadi glukosa dan fruktosa, dan yang pertama lebih dimanfaatkan dan dimetabolisme untuk menghasilkan etanol dan karbon dioksida.

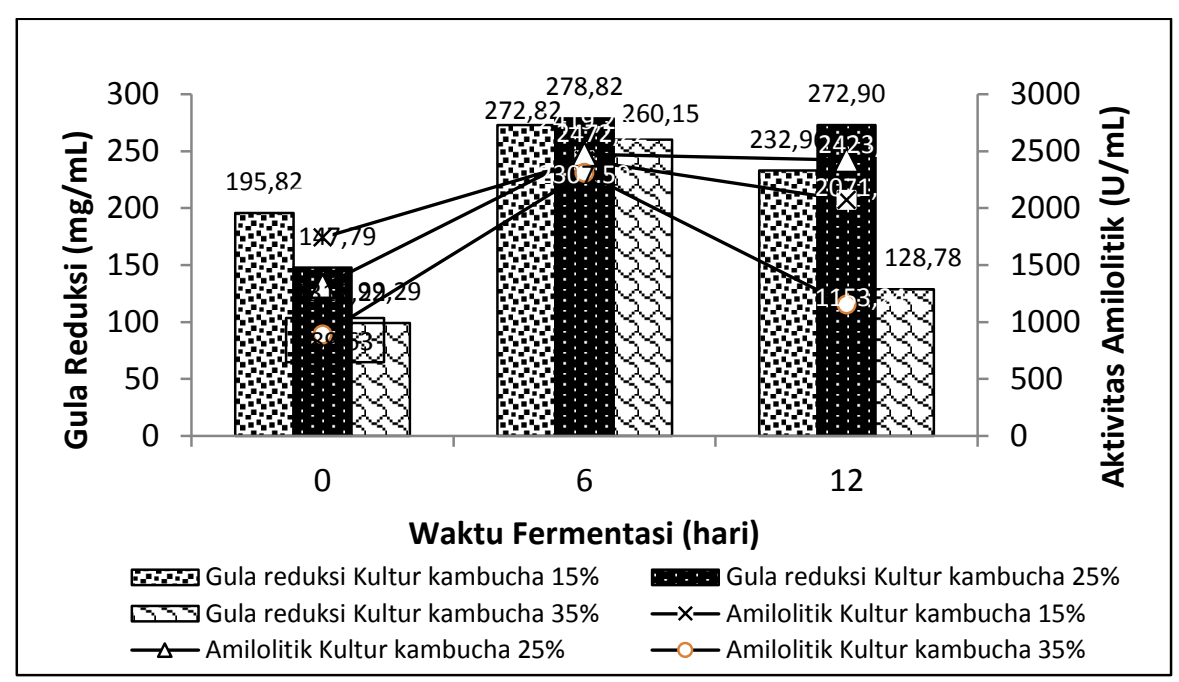

Gambar 5. Pengaruh waktu fermentasi dan konsentrasi inokulum terhadap kandungan gula reduksi dan aktivitas amilolitik hasil fermentasi ekstrak brokoli menggunakan kultur kombucha 


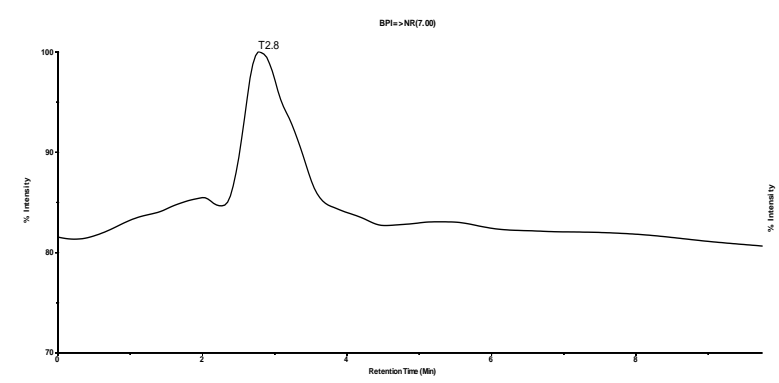

(a)

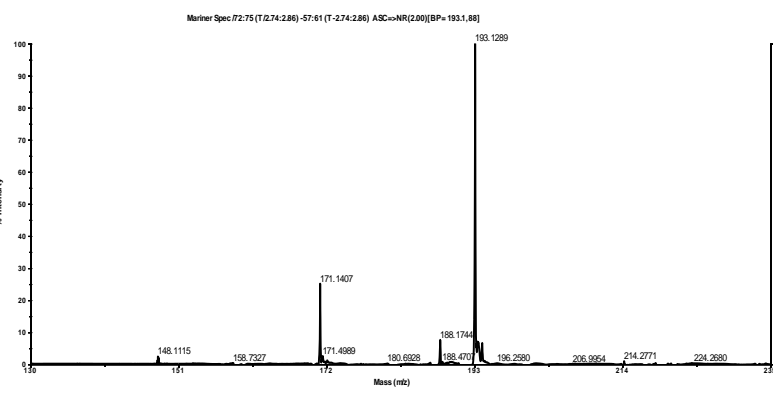

(b)

Gambar 6. Standar asam galat (a) dan mass spectra from T 2.8 dari kromatogram asam galat (b)

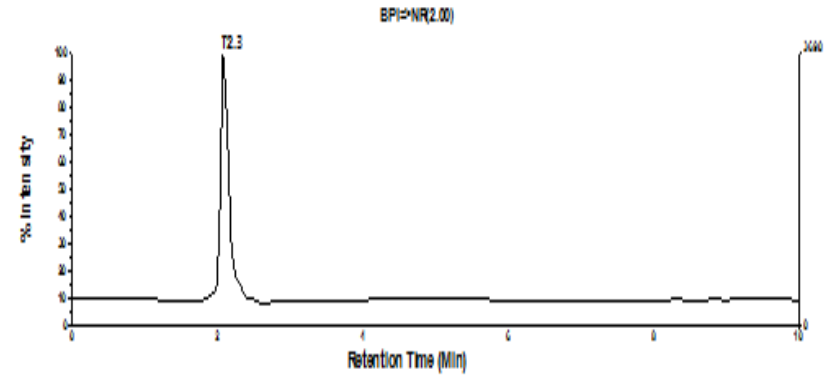

(a)

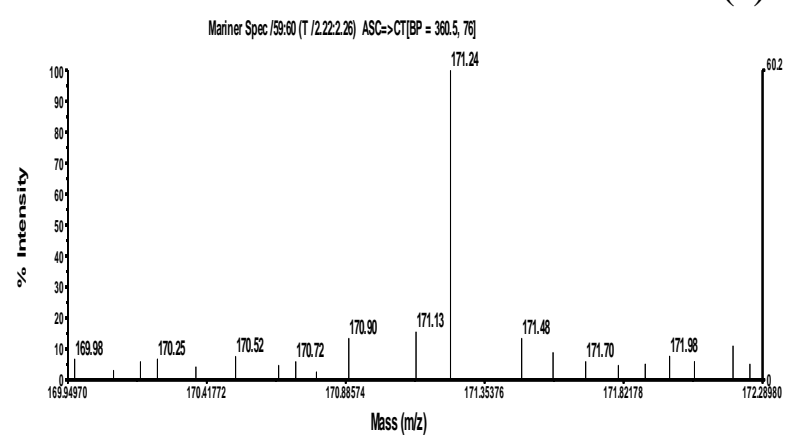

(b)

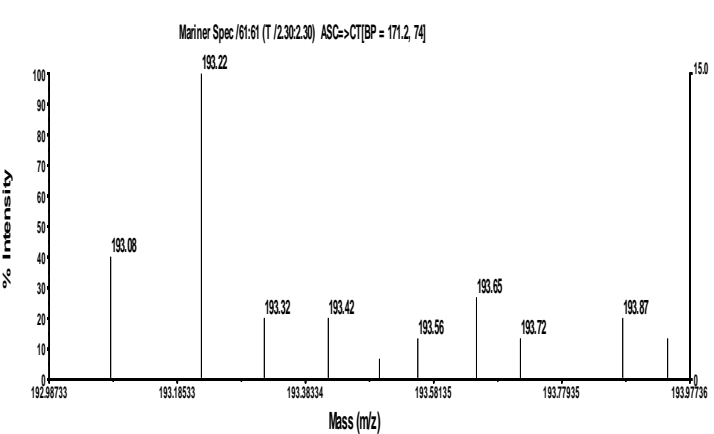

(c)

Gambar 7. Kromatogram T2.3 dalam identifikasi aktif pada ekstrak sayuran brokoli dengan kondisi proses terbaik fermentasi brokoli (a) Spektrum (b) adalah adalah pembesaran untuk menunjukkan puncak pada m/z 171 dari intensitas ion yang paling kuat dalam spektrum. Spektrum (c) adalah spektrum ion produk m/z 193 yang menunjukkan asam galat sebagai antioksidan.

\section{Identifikasi monomer asam galat sebagai antioksidan melalui LC-MS}

\section{Standar asam galat}

Identifikasi monomer pada standar asam galat dilakukan karena asam galat merupakan antioksidan. Identifikasi terhadap standar asam galat diperoleh 1 peak kromatogram dengan waktu retensi 0-10 menit yaitu $\mathrm{T} 2.8$ dengan relatif intensitas $100 \%$ dan mass spektra T 2,8 pada 99-1200 mz yang didominasi monomer berberat molekul 193,1298 Da. masing-masing seperti yang ditunjukkan 
pada Gambar 6a dan 6b. Berdasarkan LCMS diketahui bahwa dimungkinkan suatu senyawa memperlihatkan perbedaan BM dimana kemungkinannya adalah sebagai $\mathrm{M}+, \mathrm{M}+\mathrm{Na}+, 2 \mathrm{M}++$ atau 2 $\mathrm{M}++\mathrm{Na}+$. Hal ini disebabkan oleh adanya ionisasi karena sensitifitas instrumen LC-MS yang berkaitan dengan eluent yang digunakan. Kondisi operasi LC-MS adalah pada volume injeksi $5 \mu \mathrm{L}$, laju alir $0.1 \mathrm{~mL} / \mathrm{menit}$ dengan eluent campuran Metanol dan Air pada rasio 80 : 20 , menggunakan kolom C-8 (15 mm x 2 $\mathrm{mm})[3]$.

Hasil identifikasi fermentasi ekstrak brokoli dengan perlakuan kombucha konsentrasi kultur kombucha $15 \%$ dengan waktu fermentasi 6 hari, diperoleh kromatogram dengan 1 peak ( $\mathrm{T}$ 2.3) pada waktu retensi 0-10 menit seperti ditunjukkan pada Gambar 7a.

Mass spektra dari peak T 2,3 pada Gambar 7 terlihat adanya monomer asam galat yaitu dilihat dari berat molekul $171 \mathrm{Da}$ $[\mathrm{M}+\mathrm{H}]^{+}$dan berat molekul $193 \mathrm{Da}$ $[\mathrm{M}+\mathrm{H}]^{+}$. Rentang mass spektra antara 442.0 - 444.0 dan diperoleh peak dengan intensitas $100 \%$. Hasil intensitas relatif tertinggi asam galat sebesar $29,05 \%$ dan 59,96\% pada kelimpahan 60,2\% (Gambar 7). Begitupula pada mass spectra $\mathrm{m} / \mathrm{z} 193$ dengan intensitas tertinggi $28,53 \%$, pada kelimpahan $15 \%$ sebagai asam galat sebagai antioksidan dari brokoli terfermentasi pada kondisi optimum berdasarkan total polifenol tertinggi dan protein terlarut pada konsentrasi kultur $15 \%$ selama 6 hari.

\section{KESIMPULAN}

\section{Perubahan}

komponen bioaktif dari minuman fungsional ekstrak brokoli terfermentasi oleh campuran kultur kombucha dengan konsentrasi kultur kombucha yang berbeda berpengaruh terhadap total polifenol, total asam dan total sel yang dihasilkan. Kondisi optimum diperoleh berdasarkan total polifenol tertinggi pada konsentrasi kultur $15 \%$ selama fermentasi
6 hari sebesar total padatan $6,74 \%$, gula reduksi $272.81 \mathrm{mg} / \mathrm{mL}$, total asam $0,63 \%$, total polifenol $0,58 \%$, dan total sel sebesar $\log 6.48 \pm 0,05 \mathrm{cfu} / \mathrm{ml}$. Identifikasi asam galat sebagai antioksidan dan polifenol melalui LCMS diperoleh dengan berat molekul $171 \mathrm{Da}[\mathrm{M}+\mathrm{H}]^{+}$dan berat molekul $193 \mathrm{Da}[\mathrm{M}+\mathrm{H}]^{+}$.

\section{Daftar Pustaka}

[1] Dufresne, C. 2000 Tea, Kombucha, and health: a review. Food Research International 33: 409-421.

[2] Singleton VL, Lamuela-Raventos RM, 1999. Analysis of total phenols and other oxi-dation substrates and antioxidants by means of FolinCiocalteu reagent. Methods Enzymol 299:152-78

[3] Eichhorn, P., and Knepper, T. P., 2001, Electrospray ionization mass spectrometric studies on the amphoteric surfactant cocamidopropylbetaine, Journal of Masspectrometry, Vol. 36, pp. 677 684.

[4] Jayabalan, R., Subathradevi, P., Marimuthu, S., Sathishkumar, M., and Swaminathan, K., 2008, Changes in free-radical scavenging ability of kombucha tea during fermentation, Food Chemistry, Vol. 109 , pp. 227-234.

[5] Haslam, E., 2003, Thoughts on thearubigins, Phytochemistry, Vol. 64, pp. 61-73

[6] Nainggolan, J. 2009. Kajian pertumbuhan bakteri acetobacter $s p$. dalam kombucha rosela merah (hibiscus sabdariffa) pada kadar gula dan lama fermentasi yang berbeda. Tesis. Universitas Sumatra Utara: Medan.

[7] Chu, S.C., and Chen, C., 2006, Effects of origins and fermentation time on the antioxidant activities of kombucha, Food Chemistry, Vol. 98, pp. 502-507 
[8] Greenwalt CJ, RA Ledford, KH Steinkraus., 1998. Determination and Characterization of the Antimicrobial Activity of the Fermented Tea Kombucha, LWT Food Science and Technology, Volume 31, Issue 3, April 1998, Pages 291-296.

[9] Liu, C.H., Hsu, W.H., Lee, F.L., and Liao, C.C., 1996, The isolation and identification of microbes from a fermented tea beverage, Haipao, and their interactions during Haipao fermentation, Food Microbiol., Vol. 13(No. 6), pp. 407-415.
[10] Jayabalan, R, Malbasa, R.V., Loncar, E.S., Vitas, J.S., and Sathishkumar, M., 2014, A review on Kombucha teaMicrobiology,composition, fermentation, beneficial effects, toxicity, and tea fungus, Comprehensive Reviews in Food Science and Food Safety, Vol. 13, pp. 538-550.

[11] Piparo, E. L., Holger, S., Frei, N., Williamson, G., Grigorov, M., and Chou, H. J., 2008, Flavonoids for controlling starch digestion: Structural requirements for inhibiting human $\alpha$-amylase, Journal of Medicinal Chemistry, Vol. 51, pp. 3555-3561. 